\title{
PERENCANAAN DAN PENGENDALIAN PERSEDIAAN ALUMINIUM SULFAT CAIR DENGAN METODE EOQ STUDI KASUS PADA PDAM TIRTA MAYANG KOTA JAMBI
}

\author{
Diana Chandra Dewi'), Erna Rahayu EW ${ }^{2}$, Eri Suganda ${ }^{3)}$ \\ Teknik Industri, Sekolah Tinggi Teknologi Nasional Jambi \\ dianachandradewi.dc@gmail.com
}

\begin{abstract}
ABSTRAK
Penelitian ini bertujuan untuk mengetahui bagaimana Perencanan Dan Pengendalian Aluminium Sulfat Cair pada PDAM Tirta Mayang Kota Jambi dengan menggunakan metode EOQ perusahaan dapat menghasilkan biaya yang lebih murah ketika disandingkan dengan teknik yang diterapkan perusahaan selama ini. Penghematan yang didapatkan jika metode EOQ diaplikasikan pada perusahaan pada tahun 2019 yaitu senilai Rp 12.039.812,- . Berdasarkan hasil peneltian, persediaan material dengan menggunakan metode Economic Order Quantity dan total biaya persediaan bahan baku dengan metode EOQ hasil yang didapatkan telah efisien sehingga perusahaan dapat mempertimbangkan untuk menggunakan metode EOQ dalam mengadakan persediaan bahan baku aluminium sulfat cair.
\end{abstract}

Kata Kunci : Perencanaan dan Pengendalian Persediaan, EOQ, Peramalan

\section{PENDAHULUAN}

Dengan semakin pesatnya pertumbuhan penduduk dan perkembangan suatu kawasan perkotaan maka semakin meningkat pula kebutuhan masyarakat terhadap air bersih, Perusahaan Daerah Air Minum Tirta Mayang Kota Jambi selanjutnya disingkat PDAM Tirta Mayang merupakan Badan Usaha Milik Daerah yang bergerak dibidang pelayanan air minum wilayah Kota Jambi. PDAM Tirta mayang Kota Jambi saat ini telah melayani sebanyak 72.000 Sambungan rumah atau setara dengan 432.000 Jiwa.Untuk melayani masyarakat Kota Jambi PDAM Tirta Mayang memiliki instalasi pengolahan air sebanyak 8 (Delapan ) unit yang tersebar dibeberapa kecamatan di Kota Jambi yaitu :

1. IPA Broni I dengan kapasitas produksi sebesar 600 1/det

2. IPA Broni II dengan kapasitas produksi sebesar 600 1/det

3. IPA Benteng dengan kapasitas produksi sebesar $170 \mathrm{~L} / \mathrm{det}$

4. IPA Tanjung Sari dengan kapasitas produksi sebesar $200 \mathrm{~L} / \mathrm{det}$

5. IPA Aurduri dengan kapasitas produksi sebesar 200 lLdet

6. IPA Perumnas Aurduri dengan kapasitas produksi sebesar $20 \mathrm{~L} / \mathrm{det}$
7. IPA Pasir Panjang dengan kapasitas produksi sebesar $40 \mathrm{~L} / \mathrm{det}$

8. H. IPA Pasir Tanjung Johor dengan kapasitas produksi sebesar $20 \mathrm{~L} / \mathrm{det}$

PDAM Tirta Mayang Kota Jambi selama tahun 2018 telah memproduksi air bersih sebanyak $30.899 .667 \mathrm{~m} 3$ atau rata-rata 2.574 .972 $\mathrm{m} 3$ perbulan dalam melakukan proses pengolahan air PDAM menggunakan Aluminium Sulfat Cair sebagai bahan flokulasi dalam pemurnian air bersih. Kebutuhan Aluminium Sulfat Cair Selama tahun 2018 sebanyak $1.687 .240 \mathrm{Kg}$, mengingat pentingnya bahan kimia ini maka perlu dilakukan perencanaan persediaan yang tertata dan efisien karena apabila persediaan aluminium sulfat ini terganggu maka dapat menimbulkan permasalahan kualitas air olahan PDAM Tirta Mayang Kota Jambi.

Dalam proses pengolahan air di PDAM Tirta Mayang ada beberapa bahan baku yang digunakan, dalam hal ini peneliti memfokuskan pada satu bahan baku pengolahan yaitu bahan Kimia Aluminium Sulfat Cair.

Dalam mengelolaa persediaan barang maka diperlukan suatu metode, salah satu metode persediaan yang paling sering di gunakan yaitu teknik Economic Order ( Economic Order Quantity). Pada metode ini penggunaanya untuk mendapakan tingkat persediaan yang minimu deang kualitas yang baik dan harga rendah. 
Melakaukan rencana Inventory dengan teknik EOQ diharapkan mampu meminimkan terjadinya Out of Stock yang biasanya menghambat proses produksi dan juga dapat meminimumkan biaya persedaiaan material pada perusahaan. Metode ini juga diharapkan dapat mengurangi biaya simpan, Hemat ruang, dan juga mengurangin masalah penumpukan inventor yang berakibat pada stick berlebih pada ruang simpan atau gudang. (Gitosudarmo ,2002)

Berdasarkan uraian yang telah di sampiakan maka didapatkan beberapa perumusan masalah, yaitu :

1. Prakiraan Ramalan ( Forecasting ) kebutuhan aluminum Sulfat cair jangka pendek.

2. Perhitungan pembelian Aluminumsulfat cair yang paling ekonomis dengan metode Eoq.

3. Kapan PDAM Tirta Mayang Kota Jambi seharusnya melakukan pemesanan kembali ( Reorder Point /ROP) Aluminium Sulfat Cair?

4. Berapa Biaya Total ( Total Cost ) Persediaan yang diperlukan?

Dalam peneliatian ini pembahasan difokuskan pada perencanaan dan pengendalian Aluminium Sulfat Cair yang digunakan oleh PDAM Tirta Mayang yang merupakan salah satu bahan kimia dalam proses produksi diinstalasi Pengolahan Air ( IPA ) PDAM Tirta Mayang Kota Jambi.

Penelitian ini dilakukan dengan tujuan sebagai berikut :

1. Untuk dapat mengetahui estimasi kebutuhan Aluminium Sulfat Cair dalam jangka pendek 3-12 Bulan .

2. Untuk mengetahui jumlah pemesanan yang paling ekonomis dalam memenuhi persediaan terhadap Aluminium Sulfat Cair

3. Untuk dapat menetapkan kapan PDAM Tirta Mayang Kota Jambi seharusnya melakukan pemesanan kembali Aluminium Sulfat Cair.

4. Untuk dapat menghitung biaya total persediaan Aluminium Sulfat Cair yang seharusnya dikeluarkan oleh PDAM Tirta Mayang Kota Jambi.

\section{DASAR TEORI}

\section{A. Perencanaan}

Perencanaan merupakan suatu proses menetapkan sesuatu tujuan yang ingin di capai yang harus ( Schermerhorn,1996) Perencanaan ini berkaitan dengan menciptakan prosedur, aturan dan pedoman untuk pencapaian tujuan organisasi. Output dari pelaksanaan perencanaan yaitu meminimukan resiko yang diprediksi terjadi pada perusahaan .

\section{B. Pengendalian Inventory}

Persediaan merupkan hal yang penting didalam suatu perusahaan maka dari itu perlu diadakan pengendalian apada persediann agar optimal, Berikut tujuan pengendaliian persedian menurut ( Rangkuti,2000) :

a. Menyediakan suplai barang kebutuhan bagi operasi yang efisiensi dan tidak terganggu.

b. Menyediakan cukup banyak stock dalam periode kekurangan suplai dan dapat mengantisipasi perubahan yang mempengaruhi barang.

c. Menjamin cukup persediaan bagi pengiriman pada waktunya kepada pelanggan.

Terdapat empat faktor yang mempengaruhi persediaan yaitu, Faktor waktu, Faktor ketidak pastian waktu datang dari pemasok, Faktor ketidakpastian waktu penggunaan dari dalam perusahaan, Faktor ekonomis Yamit (2003).

\section{Peramalan}

Peramalan merupakan teknik dalam memperkirakan sesuatu yang akan terjadi dimasa datang dan membutuhkan banyak data masa lampau yang dibutuhkan untuk dilakukan peramalam dimasa depan dengan teknik matematis, sedangkan menurut Nasution dan Prasetyawan (2008), peramalan ialah suatu process yang memeperkirakan kebutuhan di masa depan dengan kriteria, Quality, Quantity Time dan Location. Fungsi peramalan dapat dilihat ketika keutusan telah di ambil, jika keputusan itu baik yaitu berasaskan pada pertimbangan yang terjadi pada saaat dilakukan keputusan, (Ginting, 2007).

\section{Economic Order Quantity ( EOQ)}

Dalam buku Manajemen Operasi (Operations Management) Oleh Heizer dan Render (2005) dikatakan bahwa "Model kuantitas pesanan ekonomis (Economic Order Quantity-EOQ) adalah salah satu teknik pengendalian yang paling tua dan paling dikenal secara luas". Dengan menerapkan metode ini didalam perusahaan setidaknya mampu memperhitungkan jumlah produksi dengan persediaan yang ada, dan kapan harus memesan kembali (reorder point) untuk memproduksi di tahap selanjutnya sebagai 
langkah produksi yang dilakukan secara terus menerus.

Jumlah pemesanan yang ekonomis (EOQ) adalah jumlah atau besarnya pesanan yang memiliki jumlah ordering cost atau carrying cots per tahun yang paling minimal. Biaya ini harus diusahakan sekecil-kecilnya (minimal) untuk mencapai jumlah pesanan yang paling ekonomis (Assauri,2003), beberapa faktor persedidan yang wajb dipenuhui Antara lain, pemakaian kira kira, harga material, biaya penyediaan, pemakaian asli, lead time, model pembelian bahan. Safaety stock, dan reorderpoint.

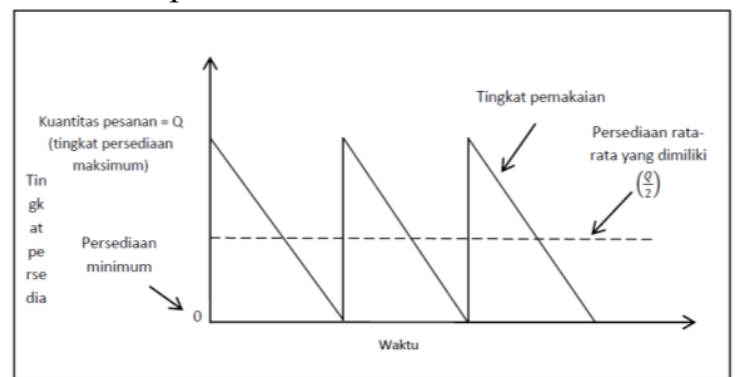

Gambar 1 Penggunaan persediaan dari waktu ke waktu (Sumber Heizer \& Render,2005).

Dengan permintaan atau penggunaan yang konstan sepanjang waktu ,maka besarnya persediaan akan menurun pada tingkat yang sama atau uniform sepanjang waktu.setiap tingkat persediaan telah mencapai nol maka pesanan baru harus diadakan dan diterima. Dengan diterimanya barang yang dipesan maka tingkat persediaan akan mencapai titik $\mathrm{Q}$ digaris vertikal.proses seperti ini akan terus berlanjut sepanjang waktu. Menurut Usry dan Lawrence (2001 : 251), metode dalam menentukan Economic Order Quantity yang mempunyai rumus sebagai

berikut:

Keterangan:

$\mathrm{EOQ}=$ jumlah pesanan yang ekonomis

$\mathrm{RU}=$ Unit kebuthan setahun

$\mathrm{CO}=$ Biaya pesnan $/$ per order

$\mathrm{CU}=$ Biaya bahan per unit

$\mathrm{CC}=$ Persntase biaya pemilkan

\section{E. Reorder Point (ROP)}

Model EOQ akan mendapatkan hasil berapa pemesanan yang optimal sedangnkan reorder point (ROP) berdsarakan kapan waktunya pemesanan dimulai atau dilakukan. ROP dilakukan ketika stock telah hamper habis maka keputusan ROP yaitu kapan waktu yang tepat atau sesuai untuk memesan kembali stock bahan baku agar tidak terlambat atau terlalu cepat.

\section{F. Sistem Penyediaan Air Minum}

Sistem Penyediaan Air Minum yang selanjutnya disingkat SPAM adalah satu kesatuan sistem fisik ( teknik ) dan non fisik dari sarana dan prasarana penyediaan Air Minum. SPAM ini meliputi SPAM Jaringan Perpipaan ( JP ) dan SPAM Bukan Jaringan Perpipaan ( BJP )

SPAM Jaringan Perpipaan yang selnjutnya disingkat SPAM JP adalah satu kesatuan sarna dan prasarana penyediaan Air Minum yang disalurkan kepada pelangan melalui sistem perpipaan. SPAM Bukan Jaringan Perpipaan yang selanjutnya disingkat SPAM BJP merpakan satu kesatuan sarana prasarana penyediaan Air Minum yang disalurkan atau diakses pelanggan tanpa sistem perpipaan.

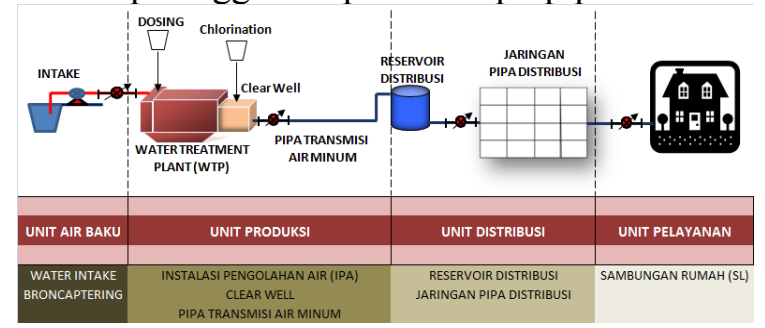

Gambar 2 Sistem Penyediaan Air Minum jaringan perpipaan

\section{Unit Air Baku}

Air baku untuk air minum rumah tangga yang selanjutnya disebut air baku adalah air yang dapat berasal dari sumber air permukaan , cekungan air tanah dan atau air hujan yang memenuhi baku mutu tertentu sebagai air baku untuk air minum. unit air baku adalah sarana dan prasarana pengambilan dan atau penyedia air baku meliputi bangunan penampungan air , bangunan pengambilan atau penyadapan,alat pengukuran dan peralatan pemantauan, sistem pemompaan serta sarana pelengkap lainnya.

\section{Unit Produksi}

unit produksi adalah sarana dan prasarana yang dapat digunakan untuk mengolah air baku menjadi air minum melalui proses fisik , kimiawi dan atau biologi meliputi bangunan pengolahan dan perlengkapannya, perangkat operasional, alat pengukuran dan peralatan pemantauan serta bangunan penampung air minum. Biasanya bangunan atau konstruksi ini 
terdiri dari 5 proses yaitu : koagulasi, flokulasi, sedimentasi, filtrasi dan desinfeksi.

\section{TEKNIK PENGUKURAN DATA}

Pada penelitian ini peneliti menggunakan metode deskriftif, Menurut Nazir (2011), "Metode penelitian deskriptif adalah suatu metode dalam meneliti status sekelompok manusia, suatu objek, suatu kondisi, suatu sistem pemilkiran, ataupun suatu kelas peristiwa pada masa sekarang". Melalui penelitian deksriptif ini peneliti bertujuan untuk memperoleh dan mendeskriptifkan bagaimana penerapan metode persediaan Economic Order Quantity (EOQ) selain dengan metode persediaan yang diterapkan oleh PDAM Tirta Mayang Kota Jambi . Tujuan dari penelitaian ini untuk mengetahui dan menganalisa teknik persediaan bahan kimia Aluminium Sulfat Cair cair di PDAM mengetahui persediaan bahan kimia Aluminium Sulfat Cair cair dengan menggunakan metode Economic Order Quantity (EOQ) di PDAM. Penelitian ini dilakukan di PDAM Tirta Mayang Kota Jambi Jl.Letkol Slamet Riyadi - Broni dengan objek penelitian persediaan Bahan Kimia Aluminium Sulfat Cair

Flow Chart Penelitian

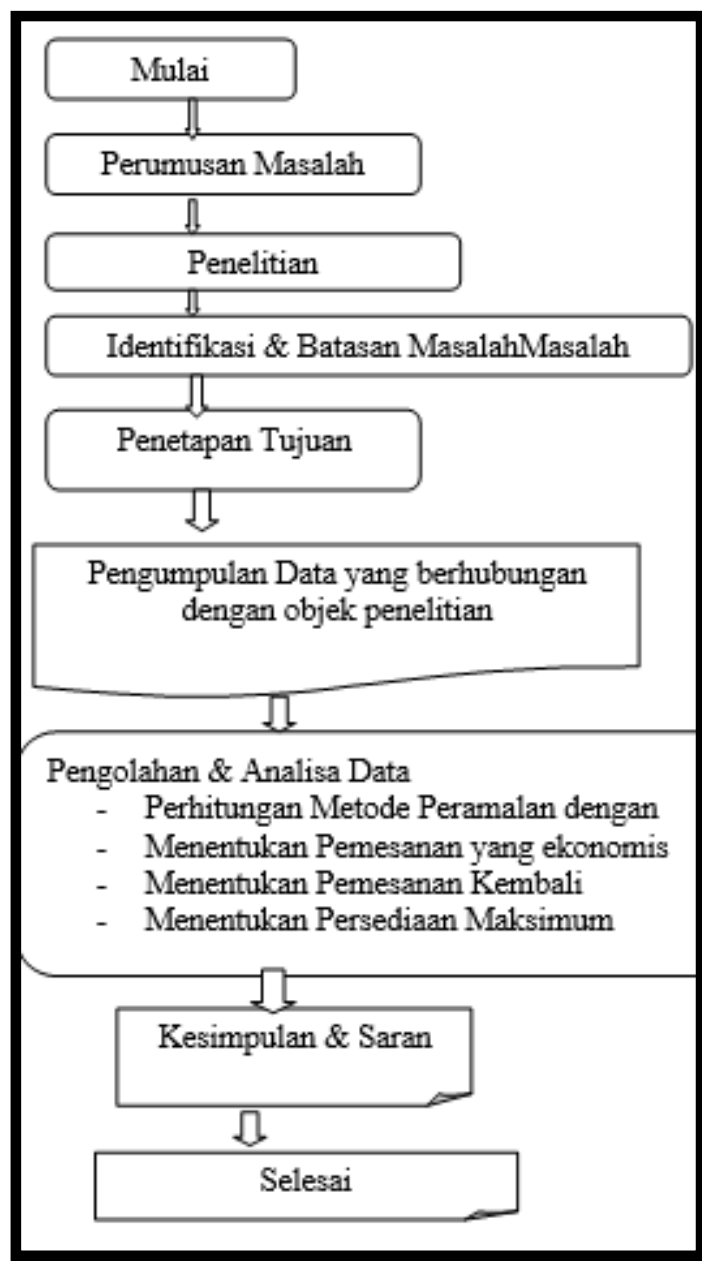

IV. HASIL DAN PEMBAHASAN Analisa Persediaan Aluminium Sulfat Cair Untuk menerapkan kebijakan persediaan Aluminium Sulfat Cair, PDAM Tirta Mayang Kota jambi melakukan perhitungan berdasarkan estimasi peningkatan produksi ditahun 2019 dibandingkan dengan realisasi pemakaian Almuninium Sulfat Cair Tahun 2018. Menentukan Prakiraan Ramalan ( Forecasting)

Dalam melakukan penelitian ini, peneliti menggunakan metode Regnesi Linear ( Linear Regression) dan menggunakan data realisasi penggunaan Aluminium Sulfat Cair tahun 2018

Tabel 1 Realisasi Pemakaian Aluminium Sulfat Cair Tahun 2018. 


\begin{tabular}{|c|c|c|}
\hline Bulan & Produksi Air & Pemakain Alum \\
\hline & M3 & Kg \\
\hline 1 & 2.555 .989 & 133.259 \\
\hline 2 & 2.676 .144 & 139.842 \\
\hline 3 & 2.519 .105 & 131.191 \\
\hline 4 & 2.655 .599 & 131.329 \\
\hline 5 & 2.515 .985 & 136.195 \\
\hline 6 & 2.357 .142 & 129.832 \\
\hline 7 & 2.523 .586 & 137.283 \\
\hline 8 & 2.448 .669 & 149.084 \\
\hline 9 & 2.443 .866 & 142.412 \\
\hline 10 & 2.464 .419 & 159.696 \\
\hline 11 & 2.509 .811 & 156.613 \\
\hline 12 & 2.445 .946 & 140.504 \\
\hline Total & 30.116 .261 & 1.687 .240 \\
\hline
\end{tabular}

Sumber : PDAM Tirta Mayang Kota Jambi Dari data tersebut maka dapat dihitung dengan metode regresi linier adalah sebagai berikut:

$$
\begin{gathered}
Y=a+b x \\
\frac{b=\sum x y-\overline{z y}}{\sum x^{2}-n \bar{x}^{2}} \\
a=\bar{y}-b \bar{x}
\end{gathered}
$$

Tabel 2.Data Pemakaian Aluminium Sulfat Cair dengan menggunakan metode regresi linear

\begin{tabular}{|l|c|c|c|c|}
\hline Bulan & $\begin{array}{c}\text { Perio } \\
\text { de }\end{array}$ & $\begin{array}{c}\text { Data } \\
\text { Pemakaian }\end{array}$ & \multicolumn{1}{l|}{} \\
\hline & $(\mathrm{x})$ & $(\mathrm{y})$ & $(\mathrm{x} . \mathrm{y})$ & $\left(\mathrm{x}^{2}\right)$ \\
\hline Januari & 1 & 133.259 & 133.259 & 1 \\
\hline Februari & 2 & 139.842 & 279.684 & 4 \\
\hline Maret & 3 & 131.191 & 393.573 & 9 \\
\hline April & 4 & 131.329 & 525.316 & 16 \\
\hline Mei & 5 & 136.195 & 680.975 & 25 \\
\hline Juni & 6 & 129.832 & 778.992 & 36 \\
\hline Juli & 7 & 137.283 & 960.981 & 49 \\
\hline Agustus & 8 & 149.084 & 1.192 .672 & 64 \\
\hline September & 9 & 142.412 & 1.281 .708 & 81 \\
\hline Oktober & 10 & 159.696 & 1.596 .960 & 100 \\
\hline November & 11 & 156.613 & 1.722 .743 & 121 \\
\hline Desember & 12 & 140.504 & 1.686 .048 & 144 \\
\hline Jumlah & $\mathbf{7 8}$ & $\mathbf{1 . 6 8 7 . 2 4 0}$ & $\mathbf{1 1 . 2 3 2 . 9 1 1}$ & $\mathbf{6 5 0}$ \\
\hline
\end{tabular}

$$
\mathrm{b}=1.859
$$

$$
\mathrm{a}=128.519
$$

setelah a dan b diketahui maka selajutnya dihitung peramalan persediaan aluminium sulfat cair untuk tahun 2019 adalah sebagai berikut ; $y=a+b(y 13), y=a+b(y 14), y=a+b(y$ dst)

\begin{tabular}{|l|l|l|}
\hline y13 & 13 & 152.687 \\
\hline y14 & 14 & 154.547 \\
\hline y15 & 15 & 156.406 \\
\hline y16 & 16 & 158.265 \\
\hline y17 & 17 & 160.124 \\
\hline y18 & 18 & 161.983 \\
\hline y19 & 19 & 163.842 \\
\hline y20 & 20 & 165.701 \\
\hline y21 & 21 & 167.560 \\
\hline y22 & 22 & 169.419 \\
\hline y23 & 23 & 171.278 \\
\hline y24 & 24 & 173.138 \\
\hline
\end{tabular}

Dari dilakukan perhitungan dengan metode Linear Regression maka diperoleh hasil sebagai berikut :

Tabel 3.Hasil Peramalan Persediaan Aluminium Sulfat cair untuk Bulan Januari sampai Desember 2019.

\begin{tabular}{|l|c|}
\hline Bulan & Persediaan $(\mathrm{Kg})$ \\
\hline Januari & 152.687 \\
\hline Februari & 154.547 \\
\hline Maret & 156.406 \\
\hline April & 158.265 \\
\hline Mei & 160.124 \\
\hline Juni & 161.983 \\
\hline Juli & 163.842 \\
\hline Agustus & 165.701 \\
\hline September & 167.560 \\
\hline Oktober & 169.419 \\
\hline November & 171.278 \\
\hline Desember & 173.138 \\
\hline Jumlah & 1.954 .950 \\
\hline
\end{tabular}

Jadi setelah dilakukan dilakukan peramalan kebutuhan aluminium Sulfat Cair untuk Tahun 
2019 dapat didapatkan persediaan sebesar $1.954 .950 \mathrm{Kg}$.

Menentukan jumlah pemesanan yang ekonomis atau Economic Order Quantity (EOQ)

Berdasarkan Peramalan persediaan yang telah dihitung diatas maka diperkirakan kebutuhan aluminium Sulfat Cair untuk Tahun 2019 adalah sebesar $1.954 .950 \mathrm{Kg}$, perkiraan harga adalah sebesar Rp.2.200 /Kg.Pemesanan akan dilakukan sebanyak 12 kali pemesanan setiap tahunnya.Ordering cost untuk bahan baku terdiri dari

- Biaya Penyiapan Pesanan

Rp. 700.000

- Biaya Penanganan pesanan tiba

Rp. 2.500 .000

- Biaya Administrasi

Rp. 1.000 .000

Total Biaya

Rp. 4.200.000

Biaya Penyimpanan ( Carrying cost ) sebesar 10 $\%$ dari biaya persediaan rata-rata terdiri dari biaya penyusutan dan perbaikan, biaya pemeliharaan,biaya keamanan dan lain-lain.

\begin{tabular}{|l|c|l|}
\hline Uraian & Biaya & Satuan \\
\hline Biaya Penyiapan & 700.000 & Rupiah \\
\hline $\begin{array}{l}\text { Biaya Penanganan } \\
\text { Pesana }\end{array}$ & 2.500 .000 & Rupiah \\
\hline Biaya Administrasi & 1.000 .000 & Rupiah \\
\hline Jumlah & $\mathbf{4 . 2 0 0 . 0 0 0}$ & Rupiah \\
\hline
\end{tabular}

\begin{tabular}{|l|l|l|}
\hline $\begin{array}{l}\text { Kebutuhan } \\
\text { Aluminium Sulfat } \\
\text { Cair Th.2019 }\end{array}$ & $\mathbf{1 . 9 5 4 . 9 5 0}$ & Kg \\
\hline $\begin{array}{l}\text { Harga Aluminium } \\
\text { Sulfat Cair }\end{array}$ & $\mathbf{2 . 2 0 0}$ & Rupiah \\
\hline
\end{tabular}

1. Perhitungan Jumlah Optimum unit per order Aluminum Sulfat Cair ( Q )

$$
\begin{aligned}
E O Q= & \sqrt{\frac{2 S D}{H}} \\
& \frac{\sqrt{2 \times 1.954 .950 \times 4.200 .000}}{R p .2 .200 \times 10 \%} \\
= & \underline{\mathbf{2 7 3 . 2 1 0 ~ K g / \text { Order }}}
\end{aligned}
$$

2. Jumlah optimum order per tahun Aluminium Sulfat Cair

$$
\begin{aligned}
&= \frac{\sqrt{1.954 .950 \times R p .2 .200 \times 10 \%}}{2 \times 4.200 .000} \\
& \mathbf{7 , 1 6} \approx \mathbf{8} \text { Kali /Tahun }
\end{aligned}
$$

3. Jumlah Optimum Hari Supply per order Aluminium Sulfat Cair

$$
\begin{aligned}
N & =\sqrt{\frac{266.450 \times R p .4 .200 .000}{121.954 .950 \times R p .2 .200 \times 10 \%}} \\
& =\mathbf{5 1} \text { hari }
\end{aligned}
$$

Dari Perhitungan yang telah dilakukan , pemesanan yang ekonomis setiap kali pemesanan adalah $\mathbf{2 7 3 . 2 1 0} \quad \mathbf{K g}$ Aluminium Sulfat Cair.Dalam setahun sebaiknya dilakukan 8 kali pemesanan dan setiap 51 hari sekali dilakukan pemesanan kembali.

Pemesanan yang biasa dilakukan oleh PDAM Tirta Mayang adalah sebanyak 12 kali, berbeda dengan hasil perhitungan jumlah pemesanan yang ekonomis.Apabila hasil perhitungan yang menggunakan Economic Order Quality ( EOQ) dibandingkan dengan pembelianyang dilakukan perusahaan akan terlihat adanya perbedaan pada total costnya.

Tabel 6. Perbandingan Biaya Persediaan Aluminium sulfat Cair antara pemesanan yang ekonomis dan Pemesanan yang dilakukan perusahaan Tahun 2019

\begin{tabular}{|l|c|c|}
\hline \multicolumn{1}{|c|}{ Uraian } & 12 Kali Order & $\begin{array}{l}8 \text { Kali } \\
\text { Order }\end{array}$ \\
\hline $\begin{array}{l}\text { Jumlah Unit per } \\
\text { order }\end{array}$ & 162.913 & 244.369 \\
\hline Nilai Persediaan & 358.407 .518 & $\begin{array}{c}537.611 .27 \\
7\end{array}$ \\
\hline $\begin{array}{l}\text { Persediaan Rata- } \\
\text { rata }\end{array}$ & 179.203 .759 & $\begin{array}{c}268.805 .63 \\
8\end{array}$ \\
\hline $\begin{array}{l}\text { Carrying } \\
\text { Cost }\end{array}$ & 17.920 .376 & 26.880 .564 \\
\hline Ordering Cost & 50.400 .000 & 29.400 .000 \\
\hline Total Cost & $\mathbf{6 8 . 3 2 0 . 3 7 6}$ & $\mathbf{5 6 . 2 8 0 . 5 6 4}$ \\
\hline
\end{tabular}

Keterangan: 
Nilai Persediaan = Jumlah unit per order $\mathrm{x}$ harga Aluminium Sulfat Cair

Persediaan rata-rata $=$ Nilai persediaan : 2

Carrying cost

$=$ Persediaan rata-rata $\mathrm{x}$

$10 \%$

Ordering cost $=$ Rp. $4.200 .000 \mathrm{x}$

jumlah oder per tahun

Total cost

$=$ carrying cost +

ordering cost

Dengan perbandingan antara perhitungan pembelian Aluminium Sulfat Cair yang diterapkan perusahaan, dapat terlihat jelas bahwa pemesanan berdasarkan Economic Order Quantity (EOQ) lebih ekonomis daripada yang dilakukan oleh perusahaan

Setelah didapatkan jumlah pemesanan yang ekonomis, perusahaan juga perlu mengetahui berapa safety stock yang harus tersedia digudang, sehingga tidak terjadi kekurangan Aluminium Sulfat Cair.

Tabel 7. Persiapan Perhitungan Standar penyimpanan Aluminium Sulfat Cair

\begin{tabular}{|c|c|c|c|c|}
\hline $\begin{array}{c}\text { Bu } \\
\text { lan }\end{array}$ & $\begin{array}{c}\text { Pemakaia } \\
\mathrm{n}\end{array}$ & \multicolumn{2}{|c|}{ Pemakaian rata-rata } & \\
\hline & $\mathrm{X}$ & $(\mathrm{x})$ & $\mathrm{X}-\mathrm{x}$ & $(\mathrm{X}-\mathrm{x}) 2$ \\
\hline 1 & 133.259 & 140.603 & $(7.344)$ & 53.939 .232 \\
\hline 2 & 139.842 & 140.603 & $(761)$ & 579.628 \\
\hline 3 & 131.191 & 140.603 & $(9.412)$ & 88.592 .019 \\
\hline 4 & 131.329 & 140.603 & $(9.274)$ & 86.013 .259 \\
\hline 5 & 136.195 & 140.603 & $(4.408)$ & 19.433 .403 \\
\hline 6 & 129.832 & 140.603 & $(10.771)$ & 116.021 .622 \\
\hline 7 & 137.283 & 140.603 & $(3.320)$ & 11.024 .613 \\
\hline 8 & 149.084 & 140.603 & 8.481 & 71.921 .707 \\
\hline 9 & 142.412 & 140.603 & 1.809 & 3.271 .275 \\
\hline 10 & 159.696 & 140.603 & 19.093 & 364.529 .920 \\
\hline 11 & 156.613 & 140.603 & 16.010 & 256.309 .427 \\
\hline 12 & 140.504 & 140.603 & 144 & 20.736 \\
\hline & $\mathbf{1 . 6 8 7 . 2 4}$ & & & $\mathbf{1 . 0 7 1 . 6 5 6 . 8 4}$ \\
\hline & & & & $\mathbf{2}$ \\
\hline
\end{tabular}

$$
\begin{aligned}
\text { Standar Deviasi } & =\sqrt{\frac{\sum(X-x)^{\wedge} 2}{n}} \\
\text { Standar Deviasi } & =\sqrt{\frac{1.071 .656 .842}{12}}
\end{aligned}
$$

$\underline{\text { Standar Deviasi }=9.450}$
Tingkat pelayanan (level of service ) persediaan pengaman kebutuhan Aluminium Sulfat Cair adalah 90\%, mengacu pada tabel Tingkat Pelayanan mka diperoleh $\mathrm{Z}$ adalah 1,28 Sehingga besarnya safety stock yaitu :

$\mathrm{SS}=$ standard deviation $\mathrm{x} \mathrm{Z}$

$=9.450 \times 1,28$

$=12.096 \mathrm{Kg}$

Jadi untuk menjaga jalannya produksi, perusahaan harus memiliki persediaan pengaman ( safety stock ) sebesar $12.096 \mathrm{Kg}$.

\section{Tingkat Pemesanan Kembali (Reorder point/ROP)}

Besarnya pemakaian Aluminium Sulfat Cair per hari adalah sebanyak $4.623 \mathrm{Kg}$ (diperoleh dari 1.687.240 : 365 ). Sedangkan jangka waktu pemesanan yang dibutuhkan ratarata 2 hari, sehingga kebutuhan Aluminium Sulfat Cair selama lead time sebesar $4.623 \mathrm{Kg}$ x 2 hari $=9.245 \mathrm{Kg}$

Reorder Point $=$ kebutuhan selama lead time + safety stock

$=9.245 \mathrm{Kg}+12.096 \mathrm{Kg}$

$=\underline{\mathbf{2 1 . 3 4 1}} \mathrm{Kg}$.

Jadi perusahaan harus mengadakan pemesanan kembali jika persediaan Aluminium Sulfat Cair tinggal tersisa sebesar $\underline{\mathbf{2 1 . 3 4 1} \mathrm{Kg}}$.

\section{Persediaan Maksimum (Maximum point)}

Berdasarkan hasil perhitungan yang telah dilakukan sebelumnya diketahui bahwa besamya EOQ untuk Aluminium Sulfat Cair sebesar 273.210 Kg dan safety stock sebesar $14.204 \mathrm{Kg}$. Besamya persediaan maksimum untuk Aluminium Sulfat Cair yang harus dimiliki oleh perusahaan sebesar :

Persediaan maksimum $=\mathrm{EOQ}+\mathrm{SS}$

$=273.210 \_\mathrm{Kg}+12.096 \mathrm{Kg}$

$=285.306 \mathrm{Kg}$

Adapun total biaya hasil persediaan Aluminium Sulfat Cair menurut perhitungan EOQ adalah sebesar Rp. 56.280.564,- sedangkan perusahaan menetapkan Rp. 68.320.376 ,- Dari perbandingan tersebut dapat diketahui adanya penghematan biaya persediaan sebesar $\mathbf{R p} \mathbf{1 2 . 0 3 9 . 8 1 2 , -}$ Dengan demikian biaya persediaan menurut perusahaan menjadi besar jumlahnya, hal ini secara tidak langsung akan mengakibatkan total biaya produksi dan harga pokok produksi yang tinggi. 
produk yang dihasilkan akan memberi manfaat yang lebih kepada perusahaan dalam usaha meningkatkan laba maksimum yang ingin dicapai perusahaan.

\section{KESIMPULAN}

Dari hasil analisis dan pembahasan tentang pengendalian persediaan Aluminium Sulfat Cair pada PDAM Tirta Mayang Kota Jambi dapat diambil kesimpulan bahwa PDAM Tirta Mayang Kota Jambi selama ini dalam pengadaan persediaan Aluminium Sulfat Cair berdasarkan pada realisasi tahun-tahun sebelumnya dan estimasi / perkiraan Kebutuhan peningkatan produksi tahun berikutnya , belum menerapkan kebijakan pemesanan yang ekonomis dalam pengendalian persediaan Aluminium Sulfat Cair. Berdasarkan hasil analisa dan Perhitungan apabila Perusahaan menerapkan metode perhitungan persediaan dengan metode Pemesanan ekonomis ( EOQ) maka perusahaan dapat memperoleh penghematan sebesar $\mathrm{Rp}$ 12.039 .812 ,-.dimana berdasarkan Perhitungan biaya yang ditetapkan perusahan memperlihatkan bahwa total cost persediaan bahan baku setahunnya sebesar Rp. 68.320.376,- ,sedangkan berdasarkan pemesanan ekonomis (Economic Order Quantity) diperoleh Rp. Rp. 56.280.564,-,

\section{DAFTAR PUSTAKA}

$\begin{array}{ccr}\text { Koesmawan A.Soebandi,Sobarsa } & \text { Kosasih } \\ \text { 2014.Manajemen } & \text { Operasi } & \text { Bagian } \\ \text { Kedua,Penerbit } & \text { Mitra } & \text { Wacana } \\ \text { Media,Jakarta } & & \end{array}$

Freddy Rangkuti, 2007. Manajemen Persediaan, PT.Raja Grafindo Persada,Jakarta.

Carter Usry, 2004. Akuntansi Biaya, Salemba Empat, Jakarta.

Sugiono. 2003. Metode Penelitian Bisnis, Cetakan Ke lima, CV. Alfabeta, Bandung.
Richardus Eko Indrajit \& Richardus Djokopranoto, 2003. Manajemcn Persediaan, Gramedia Widiasarana Indonesia, Jakarta.

Nan Lin. Alih Bahasa W. Gulo. 2002. Metodologi Penelitian, PT. Gramedia Widia Sarana Indonesia, Jakarta.

Mulyadi dan Johny Setyawan. 2000. Sistem Pengendalian Manajemcn, Edisi Kedua, Pcnerbit Bumi Aksara, Jakarta.

T. Hani Handoko. 2000. Dasar-dasar Manajemen Produksi, cetakan ke-13, BPFE, Yogyakarta. 